\title{
Addressing Poverty through Innovative Policies: A Review of the Malaysian Experience
}

\author{
Azlinda Azman*, Jamalludin Sulaiman, Mohd Taufik Mohamad, Paramjit Singh Jamir Singh, \\ Mohd Haizzan Yahaya, Syazwani Drani
}

Universiti Sains Malaysia, Penang, Malaysia
*Corresponding Author: azlindaa@usm.my

\begin{abstract}
Good health, education, housing and access to the basic needs of life are basic human rights which often the poor are deprived of. Combating poverty is therefore a policy driven approach which requires innovative planning and execution. Since independence in 1957, Malaysia's policy goal focused on developing the infrastructure and improving the agricultural sector of the country. However, the watershed event of May 13, 1969 clearly vilified all previous efforts and recognized the need for a better approach to address issues of poverty, income equality and other basic physical and human rights for national development. Thus, the four long term policies from the New Economic Policy (1971-1990) to the New Economic Model (2011-2020) and the five-year development plans has been put in placed in order to address poverty issues. Under the policies, there were broad and specific approaches and affirmative programs to alleviate poverty in the country, while working towards making Malaysia a high income nation by 2020, as envisioned in Vision 2020. Each successive policies and development plans saw great improvements in nation building efforts to improve the wellbeing of the population. This paper traces briefly the history of poverty alleviation attempts in Malaysia and discusses the policies and their impacts on the economy and social wellbeing. Each of the policies has their strengths and weaknesses and this paper seeks to share some of the innovative ideas and series of economic reforms to bring Malaysia to the level it is today. The last leg of the journey to achieve Vision 2020 necessitates uplifting of the bottom $40 \%$ to the 'middle income group'. It further concludes on the call for a more rigorous intervention from the social work perspective.
\end{abstract}

Keywords Poverty Policy, Malaysia Policies, Poverty Program, Social Work Intervention

\section{Introduction}

One of the main tasks in eradicating poverty would be to define poverty while understanding the different dimensions of poverty; and to identify who are the poor based on the definition. With many definitions and concepts available in literatures written by various parties, four common underlying concepts of poverty emerged: monetary, capability, social exclusion and participatory (Laderchi, Saith, \& Stewart, 2003). These definitions range from defining poverty through a conceptual but physical poverty line to a definition more focused on the deeper psychosocial meaning to the individuals.

The current definition of poverty that is employed by the many policy-makers, governments and researchers are simplified to absolute poverty and relative poverty. Absolute poverty is largely based on the nutritional needs of a household, while relative poverty refers to poverty relative to the standard of living of society where the household lives (United Nations Development Programme, 2007).

The Economic Planning Unit (EPU) of the Prime Minister's Office is responsible for the development planning of the nation. In order to improve the quality of life, resource utilization is optimized for Malaysia to be able to effectively compete in terms of finance and technology in the international arena. One of the nation's philosophies is to encourage economic growth with equity, based on the need for national unity and development and poverty eradication. This includes social restructuring and development of the rural economic corridor while maximizing the benefits to the people on a sustainable growth.

A poverty line income (PLI) is used to determine the national incidence of poverty. The first PLI used was estimated using the minimum cost of a food basket to meet the required caloric intake for an average Malaysian household, plus the basic non-food items. An average Malaysian household size is five based on the 1973 Household Expenditure Survey (HES)figure of 5.4 persons per household (Anand, 1983). This first PLI has several shortcomings and issues. Perumal (1992) argued that the PLI method adopted by government failed to account the urban-rural cost of living. In addition, the 1977 official poverty measurement was criticized for ignoring the 
household economies of scale in food and non-food household consumption.

In 2005, the PLI was substantially revised to make it more comprehensive than before.

The new PLI takes into consideration not only the household size, but also the demographic composition of the household as daily caloric requirements of households will vary by their age and sex. Similarly, as cost of living varies by states and stratum (urban/rural).

\section{Malaysia Five-year Development Plan and Policy Agenda}

The first five-year development plan, known as the First Malaya Plan (1956-1960) was launched in 1956 just before Malaya's independence in 1957. A legacy of the colonial rule, the first plan focused mainly on the security sector and in getting sufficient revenue to finance the Emergency expenditure. The Second Malaya Plan (1961-1965) was aimed to ensure a better economic growth; and the development of the rural and agricultural infrastructures. After the formation of Malaysia in 1963, the plan was renamed the Malaysia Plan (MP). The First Malaysia Plan was launched in 1966. Beginning the Second Malaysia Plan (1971-1975), all five-year development plans address Malaysia's policy objectives as outlined in the nation's long-term national development agendas or policies. Malaysia today is in its Tenth Malaysia Plan (2011-2015) and the current long-term policy, the New Economic Model (2011-2020).

\section{New Economic Policy (1971 - 1990)}

The watershed event in 1969 as a result of a racial riot necessitates a new long-term development agenda to address the economic imbalance between the various ethnic groups in the country (Singh, 2001; Roslan, 2003; Ahmad, 2010). The New Economic Policy was introduced in 1971. The 20-year development agenda, which ended in 1990 made Malaysia one of the most successful examples of a multiracial society, comprising the Bumiputras (which includes the Malays), the Chinese and the Indians. The Bumiputra, which literally means the son of the soil is a broader term to include the indigenous population in Sabah and Sarawak.

The imbalance of wealth distribution remained a dominant factor in the nation since the 1960s, in which the Chinese held a disproportionately bigger share of the wealth when compared to the two other main ethnic groups in the country (Reen, Mokhtar \& Singh, 2013). The household mean income per month in 1970 in Peninsular Malaysia ranged from a low of RM276 for the Malays, followed by RM478 for the Indians, RM632 for the Chinese.

Basically, the Malays were less urbanized and poverty was prevalent among them compared to the Chinese and the Indians as indicated in Table 1 and Table 2.
Table 1. Population by ethnic groups and degree of urbanization in 1957 and 1970 in census Peninsular Malaysia

\begin{tabular}{ccccc}
\hline \multirow{2}{*}{$\begin{array}{c}\text { Ethnic } \\
\text { Group }\end{array}$} & $\begin{array}{c}\text { Urban Area } \\
(\%)\end{array}$ & $\begin{array}{c}\text { Rural } \\
\text { Area (\%) }\end{array}$ & $\begin{array}{c}\text { Urban Area } \\
(\%)\end{array}$ & $\begin{array}{c}\text { Rural Area } \\
(\%)\end{array}$ \\
\hline $\begin{array}{c}\text { The } \\
\text { Malays }\end{array}$ & 11.2 & 88.8 & 14.9 & 85.1 \\
\hline $\begin{array}{c}\text { The } \\
\text { Chinese }\end{array}$ & 44.7 & 55.3 & 47.4 & 52.6 \\
\hline $\begin{array}{c}\text { The } \\
\text { Indians }\end{array}$ & 30.6 & 69.4 & 34.7 & 65.3 \\
\hline
\end{tabular}

Source: Mehden (1975).

Table 2. Household poverty by ethnic groups in Peninsular Malaysia (\%) at 1957 and 1970.

\begin{tabular}{ccccc}
\hline \multirow{2}{*}{ Ethnic Group } & \multicolumn{2}{c}{$1957 / 58$} & \multicolumn{2}{c}{1970} \\
\cline { 2 - 5 } & $\begin{array}{c}\text { Urban } \\
\text { Area (\%) }\end{array}$ & $\begin{array}{c}\text { Rural } \\
\text { Area (\%) }\end{array}$ & $\begin{array}{c}\text { Urban } \\
\text { Area (\%) }\end{array}$ & $\begin{array}{c}\text { Rural } \\
\text { Area (\%) }\end{array}$ \\
\hline $\begin{array}{c}\text { Malay } \\
\text { Households }\end{array}$ & 32.7 & 74.9 & 70.3 & 65.9 \\
\hline $\begin{array}{c}\text { Chinese } \\
\text { Households }\end{array}$ & 29.4 & 25.2 & 30.5 & 24.6 \\
\hline $\begin{array}{c}\text { Indian } \\
\text { Households }\end{array}$ & 31.5 & 44.8 & 44.9 & 31.8 \\
\hline
\end{tabular}

Source: Ikemoto (1985).

The main objective of the NEP was to eliminate economic disparities between the races and to eradicate poverty by raising income levels and increasing employment opportunities for all Malaysians irrespective of race (Jomo, 2004; Yusof, Erik \& Bart, 2006; Malaysia, 1991).

The NEP was also an affirmative action policy with its main aim to help and protect the Bumiputras (the Malays and the indigenous people) who comprised the majority of the population (Ratuva, 2002; Quah, 2010). By granting the immigrants citizenship and safeguarding their legitimate interests, the government has made it clear that the special privileges for the Bumiputras as the native people of Malaysia would be preserved and will not be questioned at any time (Reen, Mokhtar\& Singh, 2013). Article 153 of the Constitution of Malaysia grants the Yang di-Pertuan Agong (King of Malaysia) responsibility for safeguarding the special position of the Bumiputras and the legitimate interests of other communities.

Table 3. Incidence of poverty in Peninsular Malaysia, 1970 and 1990

\begin{tabular}{ccc}
\hline Ethnic Groups & $\mathbf{1 9 7 0}(\mathbf{\%})$ & $\mathbf{1 9 9 0}(\mathbf{\% )})$ \\
\hline Malays & 65.0 & 20.8 \\
\hline Chinese & 26.0 & 5.7 \\
\hline Indians & 39.0 & 8.0 \\
\hline
\end{tabular}

Source: Malaysia (1991)

During the NEP period, lasting from the Second Malaysia Plan (1971-1975) through the Fifth Malaysia Plan (1986-1990), poverty reduced significantly and employment opportunities increased. Malaysia began to experience a steady income growth and showed an increase in the quality of life of Malaysians. Although poverty reduced significantly during the NEP period, the incidence of poverty among the Malays remained relatively higher (Table 3). 


\section{National Development Policy (1991-2000)}

The National Development Policy (NDP) replaced the NEP in 1991 and continued to pursue most of the NEP policies. Implementation of the NDP was done through the sixth and seventh Malaysia Plans. The NDP widened certain social values and the working climate for the nation's development while facing the global challenge of scientific and technological advances (Economic Planning Unit, 1999). This policy also focused on making Malaysia a developed nation by the year 2020. This was a turning point for the Malaysian society to start a new way of lifestyle in becoming an informative and progressive society. The Vision 2020 highlighted several criteria to achieve its aim to make Malaysia a new developed country according to the Malaysian outlook.

The NEP and NDP had brought Malaysia to be successful in term of its socioeconomic development with an average constant GDP growth of $8 \%$ for ten years since 1988 . However, this climate did not go along to satisfy the development of labour sector positively. Many labour crises had occurred due to incapability of providing skilled manpower in certain working sectors, especially the ones that were related to scientific and technological base. Furthermore, the demand for highly skilled and technically competent manpower had increased as the result of more industrial shifts to complex technology-based production processes.

Under the NDP, the 6th Malaysian Plan underlined various programs which included social welfare, economic sector, defense sector, administrative aspects, and many others for the benefits of enhancing the standards of living of Malaysian. The NDP particularly aimed to: (1) maintain the momentum of the country's rapid economy; and (2) manage the country's economic success. The several strategies that have been devised to achieve these goals include the following:

- To encourage cooperation from the private sector.

- To minimize public spending and increase revenue.

- To strengthen the capital market.

- To diversify economic base.

- To improve the distribution of wealth across all groups and regions.

- To assist Bumiputera's entrepreneurs.

It was during the tabling of the $6^{\text {th }}$ Malaysia Plan, that the government announced the Vision 2020, a vision calling for Malaysia to become a fully developed and self-sufficient industrialized nation by 2020 .

Succeeding the $6^{\text {th }}$ Malaysian Plan, the $7^{\text {th }}$ Malaysia Plan was envisioned to bring the nation into the $21^{\text {st }}$ century effectively. These plans were designed based on new strategies for dealing with the challenges and changes faced by the society and the economy. This plan maintained the concept of a balanced development division in the proceedings of the previous plan. It also included plans to delegate economic wealth equitably to all ethnic groups in Malaysia.

Among the new strategies implemented were growth strategy driven by investment. In addition, the transition was made on a large scale on export activities of Malaysian industry. The $7^{\text {th }}$ Malaysia Plan also emphasized further the importance of human resources in the areas of training and education. The new strategy also enriched the science and technology sectors, while continuing to generate the private sector development in the national economy.

Although the economy was rapidly blooming in 1996, the $7^{\text {th }}$ Malaysia Plan was remembered for its success through a difficult period during the economic deterioration in 1998. Economic development was badly affected by the emergence of the Asian Financial Crisis of 1997, which required the government to take quick actions to manage the crisis. Among them was the creation of the National Economic Action Council (NEAC) on January 7, 1998 and the National Economic Enhancement Plan (NERP) on July 23, 1998. In 2000, statistics showed that the above efforts helped the economy achieved the growth rate back to the pre-crisis level. With better relative price stability and low unemployment rate, incidence of poverty also decreased.

\section{National Vision Policy (2001-2010)}

The $8^{\text {th }}$ Malaysian Plan (2001-2005) was the first phase of the implementation of the National Vision Policy (NVP) (2001-2010) to determine the direction of the first decade of the $21^{\text {st }}$ century. The plan combined the strategies, programs and projects designed to achieve the objectives of NVP. In addition, it also encouraged sustainable growth and strengthened the resilience of the economy and society that was united and equitable.

The NVP incorporated the critical core development policies of the past, the NEP and the NDP, with the main objectives to achieve national unity. The eradication of poverty was irrespective of race, with restructuring and a balanced development as the main strategy. The NVP also guided the strategic challenges of Vision 2020.

Thus, a new dimension of the NVP was to develop a knowledge-based society. In addition, it was also aimed to accelerate growth by strengthening domestic investment and attract Foreign Direct Investor (FDI) and a more dynamic agricultural, manufacturing and services through greater application of knowledge. The dimension of the NVP also included the eradication of poverty in small remote areas such as the indigenous and Bumiputera minorities in Sabah and Sarawak. It also focused on poverty alleviation among the poorest poor while reducing relative poverty.

The 30\% target of Bumiputera equity by 2010 remains an active agenda. It also included an increase of Bumiputera participation in the economic and human resource development based on knowledge-based society. With 
previous successes in elevating poverty, it was no longer a major issue in the NVP. In order to reduce the gap in household income, and to provide more opportunity for low-income earners, education and training programmes were further simplified. The cooperation of the private sector and non-government organizations (NGOs) was encouraged to support and complement these efforts (Institut Pendidikan Perguruan Islam, 2011).

Eradication of poverty was a fundamental objective of the development of Malaysian Government since it achieved independence in 1957. Starting as commodity-exporting country such as rubber, tin, palm oil and petroleum, Malaysia experienced an increase up to $7 \%$ of total income since 1970-2000. From 2001 to 2010, the phenomenon of ascending and descending rate of income between $4-5 \%$ per annum was primarily due to less favorable economic climate. The big impact of the increase in income was the reduction of poverty compared to the rate in 1970 .

The New Economic Policy (NEP) was introduced in 1971 as the core of poverty eradication (Shafii, Abiddi \& Ahmad, 2009). After twenty years, poverty has declined to 15.1 percent. The NDP was to peruse a more balanced development policy which had been enacted to eradicate extreme poverty and reduce relative poverty between ethnic groups.

The first Millennium Development Goal (MDG) of the United Nations is to eradicate extreme poverty and hunger. In line with the MDG, the Malaysian Government had set a target under the $9^{\text {th }}$ Malaysian Plan in 2006 to eradicate extreme poverty and to reduce overall poverty to $2.8 \%$ by the end of 2010 (Nair, 2000). The per capita income increased to US\$14,700 in 2010, up from US\$13,900 in 2009. These achievements made Malaysia an upper middle income country, a situation that reflected the rapid economic growth that had been sustained since the government introduced a number of policies that support the effort towards poverty eradication and community restructuring (Zainuddin, 2011).

Subsequently, some methods or strategies of eradication of poverty and income distribution had been highlighted by the Government. Among them are through:

1. Sustaining economic growth,

2. Encouraging private investment in the state,

3. Continued fiscal policy and prudent financial,

4. Broadening and deepening the capital market, and

5. Increasing productivity.

Thus, the most important element that Malaysia has adopted over the past 50 years was to enact the policies, which will diversify the sources of income for the economy to grow and to take into account of the sociopolitical community of the different races. The introduction of the Privatization Policy in 1983, accentuates the country as a single corporation for providing the enabling environment for private parties and corporate development country. The immediate effect of this policy is the increase of the government tax revenue, in which it can be used to provide the basic needs of the population, especially in the rural areas.

\section{New Economic Model (2010 - 2020)}

Malaysia is now under its fourth long-term policy agenda, the New Economic Model (2010-2020), with the aim to propel Malaysia achieve its Vision 2020 through its four key pillars of national transformation: (1) 1Malaysia; (2) Government Transformation Program (GTP); (3) the $10^{\text {th }}$ Malaysian Plan; and (4) Economic Transformation Program (ETP). The New Economic Model that becomes one of the backbones of ETP is the Government's attempt to respond to the static condition of Malaysian economic in the $21^{\text {st }}$ century (National Economic Advisory Council, n.d.).

Although a country with abundance of natural resources, one of the challenges Malaysia has to face is the "Middle Income Trap" that disables the nation from pursuing the status of a high-income country. This is a multidimensional issue as it is contributed by not just the widening gap between the rich and the poor, but also the worrying number of "brain drain" (Kwek, 2011). Some suggest that this can be overcome through a strong establishment of research and development (R\&D) and attractive invitation for investments (Nallari, Yusuf, Griffith, \& Bhattacharya, 2011).

Statistics show that Malaysia has enjoyed poverty decrease from $0.7 \%$ in 2009 to $0.2 \%$ in 2012 , and extreme poverty from $3.1 \%$ in 2009 to $1.5 \%$ in 2012 , a commendable achievement (Department of Statistics Malaysia, 2013). The next agenda is to enable Malaysians at the bottom $40 \%$ to make a transition to middle-income group and at the same time to further reduce, if not eradicate extreme poverty. However, the transition from the middle-income group to the high-income group is still the greatest challenge yet.

Therefore, the main mission and goal of the Malaysian economy in the $21^{\text {st }}$ century might have to shift from eradicating poverty to uplifting the middle-income group to a high-income group. This is especially true as the per capita income has been forecasted to increase from US\$9,693 in 2011 to US\$10,296 in 2013 (Economic Planning Unit, 2012).

\section{A Call for Social Work Intervention}

The existing policies that was introduced and implemented by the Malaysian government do have significant impact on the nation's poverty eradication efforts. Appropriate intervention from the many responsible government and non-government agencies has been crucial to support and to realize the government policies. The social work profession can and has a major role in strengthening and supporting these poverty eradication efforts. Since social workers primarily work with the more marginalized or disadvantaged groups, including those from the poor households, thus a more rigorous intervention is expected to accelerate the targeted vulnerable population's economic and social wellbeing. While giving monetary support or subsidy to the vulnerable population groups helps, this approach is not sustainable. Social workers are trained to 
empower them to be independent and less reliant on welfare handouts. This is achievable through the many roles of social workers as a change agent or catalyst, enabler and empowerer in helping the poor regardless of ethnic races to develop the needed skills that can get them out of the poverty cycle. The idea of "productive welfare", a relatively new concept that was recently introduced by the Malaysian government through its Department of Social Welfare is certainly a great move to encourage the poor or vulnerable groups to venture into becoming a more successful social entrepreneur (www.jkm.gov.my). It is envisaged to assist those who are receiving financial aid from the government should be empowered to become more independent in sustaining their daily lives. The primary idea is to allow the poor or vulnerable population to be out of the poverty cycle and be equipped with the relevant survival skills. In doing so, strong support and monitoring from the relevant agencies or stakeholders is critical, and this would also include the contribution of social workers in guiding the poor or more vulnerable groups to move forward in sustaining their livelihood.

\section{Conclusions}

In conclusion, Malaysia has reached a stage where it has become more critical to deploy and manage the country's human resources with greater efficiency by increasing productivity and ensuring a sustainable economic development and encourage harmonious industrial relations in the organization throughout all the development programs. It is believed to be a prerequisite to the future competitiveness of the nation on ultimately accomplishing the success of Vision 2020 by establishing a balanced social economic policy for the multicultural societies according to the Malaysian outlook. Since the introduction of the 20-year New Economic Policy in 1971, the 10-year New Development Policy in 1991, the New Vision Policy in 2001 and the New Economic Model in 2011, Malaysia has been able to achieve continuous year-to-year economic growth. Incidence of poverty decreased substantially, thus realizing the aspiration of the long-term development plans as was envisioned by the Malaysia's leaders.

Efforts to reduce poverty were achieved through eight critical strategies (Economic Planning Unit, 2012) including introducing a new definition of poverty, targeting the hardcore poor through special programs, and providing direct welfare assistance to the not employable aged or disabled poor. Other strategies include improving the quality of life of the poor by providing social amenities (clean water, electricity, health services), better infrastructure, while involving the private sector and non-governmental organizations.

In summary, the continuous development of poverty programs, combined with Malaysia's rapid economic growth, helped to reduce poverty and improve the quality of life of all Malaysians. There is a strong reason to believe that the major portion of the increase in the household income of the poor accrued from non-agricultural economic activities is contributed by these development programs. It is also important to take note of the contribution from the many professionals, including the social workers in continuously empowering the society to a greater height, in parallel to government's transformation agenda which also aims to eradicate poverty.

\section{REFERENCES}

Ahmad, A. M. (2010). The genesis of a new culture: Prime Minister Mahathir's legacy in translating and transforming the new Malays. Human Communication: A Publication of the Pacific and Asian Communication Association, 13(3), 137-153.

Anand, S. (1983).Inequality and poverty in Malaysia: Measurement and decomposition. Washington, DC: Oxford University Press for the World Bank.

Department of Statistics Malaysia. (2013). Penemuan penyiasatan pendapatan isi rumah 2012. Retrieved from Jabatan Perangkaan Malaysia: R_2012_BM.pdf

Department of Statistics.(1998b). Compendium of Environmental Statistics. Department of Statistics, Malaysia.

Department of Social Welfare. (2014). Productive Welfare. Retrieved from www.jkm.gov.my

Economic Planning Unit.(1999).Malaysian Quality of Life 1999. Economic Planning Unit, Kuala Lumpur.

Economic Planning Unit.(2012). The Malaysian economy in figures. Retrieved from Economic Planning Unit: http://www.epu.gov.my/documents/10124/72ac36d7-fe5a 489b-a34c-a2cb2be073a6

Ikemoto, Y. (1985). Income distribution in Malaysia: 1957-80. The Developing Economies, vol. XXIII, no. 4, pp. 347-67.

Institut Pendidikan Perguruan Islam (2011). Meningkatkan Keutuhan. Retrieved from

www.ipislam.edu.my/index.php/artikel/read/335/BAB00MENING KATKAN-KEUTUHAN

Jomo, K. S. (2004). The New Economic Policy and interethnic relations in Malaysia. United Nations Research Institute for Social Development.

Kwek, K.-T. (2011). New Economic Model: What lies ahead for Malaysia. Economic Regional Outlook, pp. 106-108.

Laderchi, C. R., Saith, R., \& Stewart, F. (2003). Does it matter that we do not agree on the definition of poverty? A comparison of four approaches. Oxford Development Studies, 31, 243-274.

Malaysia (1991). The second outline perspective plan, 1991-2000. Kuala Lumpur: National Printing Department.

Nair, S. (2000).Poverty in the new millennium-challenges for Malaysia. Retrieved from

http://www.google.com/search/poverty+in+Malaysia.html

Nallari, R., Yusuf, S., Griffith, B., \& Bhattacharya, R. (2011).Frontiers in development policy: A primer on emerging 
issues. Washington: World Bank Publications.

National Economic Advisory Council.(n.d.).New Economic Model for Malaysia Part 1. Putrajaya: Percetakan Nasional Malaysia Berhad.

Perumal, M. (1992). New budget standard poverty lines for Malaysia. Review of Income and Wealth, 38(3), 341-353.

Quah, D. (2010). Malaysia's New Economic Model: Making choices. New Straits Times. Retrieved from http://www.btimes.com.my/Current_News/BTIMES/articles/ quah/Article/.

Ratuva, S. (2002).Affirmative action and good governance: Some lessons for Vanuatu. Paper presented at Vanuatu Governance, University of South Pacific, Vanuatu.

Reen, A. C., Mokhtar, K. S., \& Singh, P. (2013). New Economic Policy 1970-1990 in Malaysia: The economic and political perspectives. Journal of Law and Social Science, 2 (2).

Roslan, A. H. (2003). Income inequality, poverty and redistribution policy in Malaysia. Asian Profile, 31(3).

Shafii, U., Abiddi,. Z. N., and Ahmad, R. A. (2009). Ethnic Heterogeneity in the Malaysian Economy: A Special reference to the ethnic group participation in financial planning activities The Journal of International Social Research Vol2/8 Summer.

Singh, H. (2001). Ethnic conflict in Malaysia revisited. Commonwealth and Comparative Politics, 39(1), 42-43.

United Nations Development Programme. (2007). Malaysia: Measuring and monitoring poverty and inequality. Damansara: United Nations.

Yusof, M. S., Erik, D., \& Bart, L. (2006). An analysis of income distribution across ethnic groups in Malaysia: Results for a new social accounting matrix. University of Groningen, European Network for Input-Output Studies.

Zainuddin, Z. (2011). Strategi dalam dasar membasmi kemiskinan di Malaysia, perspektif sosioekonomi. Retrieved from http://zahirzainudin.blogspot.com/2011/11/strategi-dalam-dasar-m embasmi.html 